\section{The Accumulation of 3-Iodo N,N, Diacet-6 Aminobenzoic Acid (IDAB) in Growth Areas of Bone ${ }^{1}$}

ScHORR et al. ${ }^{2,3}$ found that new bone formation in malignant bone conditions, osteolytic and osteoplastic, are stained selectively in vivo by alizarin sulphonate. After experiments applying $\mathrm{I}^{\mathbf{1 3 1}}$ labelled 4-iodo alizarine had failed due to the fast deiodisation of this compound ${ }^{4}$, the behaviour in vivo of 3-iodo N, N diacet-6-aminobenzoic acid labelled with iodine 131 was investigated. This reagent, which probably acts as a tridentate chelating agent, gave positive results, showing superior affinity for new bone formations, as compared to iodo alizarin sulphonic acid.

Experimental. 3 iodo $\mathrm{N}, \mathrm{N}$, diacet-6-aminobenzoic acid

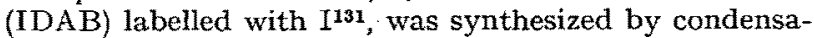
tion of 4-iodo anthranilic acid with chloroatic acid.

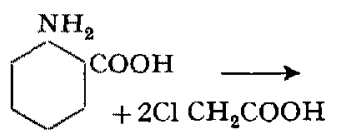

I

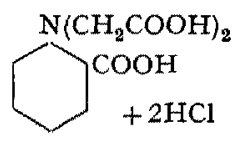

I
The labelled IDAB had a specific activity of 1 microcurie/mg and it was used until the activity dropped to one tenth of this value. $0.2,1.0$, and $5 \%$ solutions of IDAB at $\mathrm{pH}$ 6-7.5 were injected intraperitonally to young rats (average weight $100 \mathrm{~g}$ ), which were subsequently sacrificed at predetermined intervals. The specific activity of the fresh tissues was determined and expressed as counts/ $\mathrm{min} / \mathrm{g}$ tissue. The relative specific activity is defined as the ratio of the specific activity of a given tissue to that of blood. The \% of injected dose was calculated from the activity of the injected dose compared to the activities found in tissues, counted under the same conditions and corrected for the decay of iodine 131 . Doses over $10 \mathrm{mg}$ were injected either in a single injection or by repeated injections of $10 \mathrm{mg}$ each, at $2 \mathrm{~h}$ intervals. No toxic effects were observed even after doses of $200 \mathrm{mg} / \mathrm{rat}$. The callus in rats and in rabbit were produced by deliberate fracture of the tibia. In the in vivo tracing experiment, a dose of 500 microcuries of labelled IDAB in $2 \mathrm{ml}$ of $1 \%$ solution was injected to a rabbit $(1200 \mathrm{~g})$, the tibia of which was fractured five days before the IDAB administration. The legs of the rabbit were scanned with a medical type collimated scintillation counter.

Results and Discussion. Table I presents the concentrations of IDAB in blood, epiphyses, and in the thyroid gland, related to the injected dose. From this Table the fate of the injected drug may be seen. The data are calculated assuming that the average $100 \mathrm{~g}$ rat has $5.5 \mathrm{~g}$ of blood, $2.5 \mathrm{~g}$ of epiphyses, and $10 \mathrm{mg}$ of thyroid tissue. The specific activity found in other tissues, e.g. muscle and liver, did not differ appreciably from that found in blood.

The biological half-lives for the retention of the $\mathrm{I}^{131}$ activity in rats were derived graphically. It was found that IDAB is cleared from blood in the first few hours, with a biological half-life of $2 \mathrm{~h}$. Later the excretion rate is reduced, and between 8-64 h after injection, a biological half-life of $20 \mathrm{~h}$ was observed.

The concentration of IDAB in bone drops at a much slower rate, namely with an estimated biological half-life of over $100 \mathrm{~h}$. The difference between the rate of clearance of IDAB from blood and from bone, results in a rise of the relative concentration of $I D A B$ in bone as compared to that in blood.
Tab. I. The Fraction of the Injected Dose Retained in Blood, Thyroid, and Epiphyses after Injection of $10 \mathrm{mg}$ IDAB (\% of injected dose).

\begin{tabular}{|l|cccccccc|}
\hline Time (h) & 0.5 & 2 & 4 & 8 & 16 & 24 & 36 & 64 \\
\hline Blood & 7.3 & 2.0 & 0.59 & 0.25 & 0.13 & 0.14 & 0.073 & 0.036 \\
Thyroid & 0.087 & 0.048 & 0.055 & 0.092 & 0.058 & 0.037 & 0.028 & 0.045 \\
Bone & 2.7 & 1.9 & 0.8 & 0.47 & 0.45 & 0.59 & 0.41 & 0.38 \\
\hline
\end{tabular}

Tab. II. The Effect of Dose and Rate of Administration on the Relative Concentrations and on the Percentage of Injected Dose Accumulated in $1 \mathrm{~g}$ of Epiphyses.

(Rats sacrificed $32-36 \mathrm{~h}$ after last injection)

\begin{tabular}{|c|c|c|c|}
\hline Single Dose & $\begin{array}{c}\text { Repeated } \\
\text { Doses }\end{array}$ & $\begin{array}{c}\text { Relative } \\
\text { Spec. conc. }\end{array}$ & $\begin{array}{c}\% \text { of } \\
\text { injected dose }\end{array}$ \\
\hline $10 \mathrm{mg}$ & $5 \times \overline{5} \mathrm{mg}$ & 11.7 & 0.16 \\
- & 5.0 & 0.12 \\
$50 \mathrm{mg}$ & $4 \times 10 \mathrm{mg}$ & 8.7 & 0.14 \\
- & $4 \times 50 \mathrm{mg}$ & 12.5 & 0.16 \\
\hline
\end{tabular}

It was found that various bone tissues show different affinity for IDAB; epiphyses, skull, and callus formation accumulate IDAB to a higher extent than other bones. The differences between the relative concentrations in the various bone tissues diminishes with time.

The effect of dose of IDAB and its rate of administration is demonstrated in Table.II.

It may be concluded that whatever dose of IDAB is administered to rats, disregarding rate of administration, we found about $0.15 \%$ of the injected dose/g of average bone tissue, with local concentrations two fold higher in areas of rapidly growing bone. Taking the rate of excretion of IDAB into consideration, these values suggested its application for the detection in vivo of growing parts of bone. In a preliminary experiment, a callus formation in the tibia of a rabbit was detectable by in vivo scanning. Ten days after administration of IDAB, a local activity 6 fold higher than in neighbouring bones was demonstrated.

M. Anbar, I. Aviad, R. Rein, and S. SCHORR

Isotope Department. The Weizmann Institute of Science, Rehovoth, and the X-Ray Department of the Hadassah University Hospital, Jerusalem and the Hadassah Municipal Hospital, Tel-Aviv (Israel), March 16, 1960

\section{Résumé}

IDAB marqué avec Iode 131 était administré aux rats pour déterminer sa distribution entre les tissus des rats. On trouve que IDAB est accumulé selectivement par les parties croissantes des os. Deux ou trois jours après l'injection, l'activité spécifique des os était vingt fois plus grande que celle qui se trouve dans le sang.

1 This investigation was supported by the James Picker Foundation on recommendation of the Committee on Radiology, National Academy of Sciences National Research Council, Washington.

2 S. Schorr and J. Aviad, Harefuab 56,53 (1959).

3 S. Schorr, J. AVIAD, and A. LAUfER, Radiology 73, 410 (1959)

4 S. Schorr, J. Aviad, M. Anbar, and R. Rein, Amer. J. Roentgenol., in press. 